\title{
The Knowledge Transfer of Female Micro Enterprises through Community-Services University Training Programs
}

\author{
Nurul Asiah'1, Wahyudi David², Tuti Widiastuti ${ }^{2}$ \\ 1,2 Universitas Bakrie, Indonesia
}

\begin{abstract}
A B S T R A C T
This study is aiming to observe the role of community-services university training program to the participants knowledge on doing a micro enterprises and how effective the program to enhance the participant knowledge. The female micro enterprise group (18 persons) in South Jakarta was observed throughout the 5 months coaching. This study is applying the quantitative data collection based on the questionnaire and distributed prior and after the training programs. The finding of this study was the motivation of the most participant was household financial factors followed by hobby, skill of the participant as well as social factors. Most of the participant has been exposed by information through internet and they are most likely learns from internet. Training is the second sources for them for getting information. Financial investment and information of investment was the main obstacle for them to enhance their business beside managerial issues. This study found that training effectively delivers cognitive knowledge to the participant. This study concludes that training program may enhance the knowledge but further training is needed to enhance their attitude in doing business.

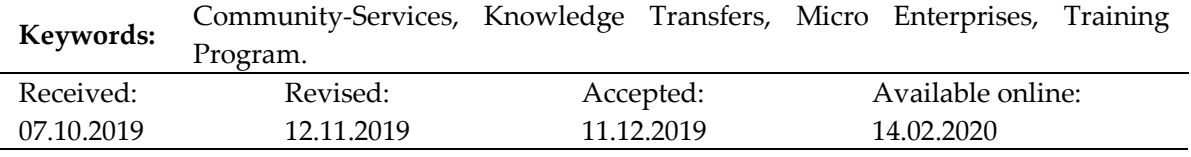

\section{Suggested citation:}

Asiah, N., David, W., \& Widiastuti, T. (2020). The knowledge transfer of female micro enterprises through community-services university training programs. Jurnal Pengabdian Pada Masyarakat, 5(1), 99-108. https://doi.org/10.30653/002.202051.260

Open Access I URL: http://ppm.ejournal.id/index.php/pengabdian/article/view/260

\footnotetext{
${ }^{1}$ Nurul Asiah: Food Science and Technology Department, Universitas Bakrie; Jl. H.R, Rasuna Said Kav C-22 Kuningan, Jakarta 12920, Indonesia; Email: nurul.itpub@gmail.com
} 


\section{INTRODUCTION}

Community service is considered as one of the principles of the higher education in Indonesia. The activity or program is rated as one of the tasks were institution, lecturers and students are required to accomplish. The coverage of the programs includes social service, seminars and workshops, training of its members and activities in cooperation with other elements of the society. One of the activities is likely to encourage small scale enterprise and support their community to overcome the business challenges. Most of the activities are multi stakeholder as well as multi-disciplinary approaches. The community services would workable if the program is designed based on the participant oriented as well as the knowledge transfer packages was offered.

Knowledge transfer refers to sharing of the knowledge as well as providing input for problem solving. The program the knowledge transfer is using, mostly involving active both participant as well as the coach. As the most of entrepreneurship skill need the activities which are involve knowledge, creativity, as well as communication skill, the program needs to combine most of them in one package.

Entrepreneurship has real potential in supporting development in the economic sector (Irawati, 2018). Furthermore entrepreneurship is one of the best way for women's empowerment in social, economic, politic and some other field of life. It can also increase family status and self-confidence (Pandey, 2015). The definition of woman entrepreneur is a person who create business idea produce innovative business ideas over existing idea by evaluating the best opportunity, brings together the production factors, taking into account possible risks and assuming these risks, profit oriented creates emotional difference and can transform this into creative design in product and services (Ozsungur, 2019).

The increase in number of female business is motivated by earning some money, generate high profit, achieve their goals, exploit business opportunities and have more flexible works schedule. Even though sometimes they do business without have enough spirit and capability of entrepreneurship (Tambunan, 2017). The lack of knowledge, skills, experiences, training, access to capital, are obstacles for the female micro entrepreneur to succeed (Shmiln, 2017). Moreover micro business activity has low income due to less educated, lack of skills, do not has access to capital and enterprise development training (Al Mamun et al, 2016).

In high competition environment, the improvements of business activities become needed for business sustainability (Hani et al, 2012). Business performance enhancement can be accelerated through training program so that businesses can be run more efficiently (Aisyah et al, 2017). Education plays a key role and vitally needed for entrepreneurs. The entrepreneurship education should be given not only prior to start business or at the beginning of business but also must be provided parallel during the business has operated. It will help them to face the dynamic changes of the market behaviour (Ismail, 2013). Continuous training and lifelong learning are crucial for the sustainable success, productivity and innovation of enterprises. There are three dimensions entrepreneurial performance i.e.: 1) economic dimension such as market share, sales and profit growth, 2) individual dimension such as self-confidence, personal life quality and personal satisfaction, 3) social dimension such as social relationship, public visibility and contribution to society (Schneide, 2017). 
There are some competences that are needed for micro entrepreneurs, such as conceptual competence for thinking and analysing in various situation, human relations competences (i.e. communication skill), decision making competence to solve problems and competence of time management (Eravia et al, 2015). The competencies can be developed by training and accumulation of experience (Behling, 2017). Training activities include guiding, correcting, advising, mediating, advocating, facilitating, educating and supervising micro-businesses to grow into productive and competitive business. Despite, existing training programs generally designed and organised from the point of view larger business and as affected it do not fit into smaller business. So the important thing what should be done before design training programs is identifying the problems and what participant needs. Then addressing internal barriers and obstacles and finding appropriate methods for training (Farvaque, Voss, Lefebvre, \& Schutze, 2009).

Although some business training programs give positive impact on women entrepreneurs (Siba, 2019), still information on how much the improvement has been obtained from the training results is still very limited. Micro business improvement requires a proper strategy through intensive and measurable education and coaching. This research was conducted to study the motivation, learning behaviour and measured the increasing of knowledge and understanding micro business entrepreneur after training programs. Further, the knowledge can be applied to enhance quality and productivity of female micro enterprises.

\section{METHODS}

This study applied quantitative approach by collecting data from questionnaires. The respondents are 18 people's community members of creative women who have micro business activities located in the Pancoran area (South Jakarta-Indonesia). This community have various types of micro businesses activities ranging from food area (snacks, cake and bakery, catering, side dish, and beverage) and non-food area (cosmetic handicrafts, fashion and retail). The age range of participant is 25-50 years old with heterogeneity in the education level. The data was collected by survey using questionnaires which divided in two sections which have different objective. The schematic research methodology flow described by Figure 1.

The first questionnaire was made to observe the motivation of doing business, training obstacles and the frequencies of attending training programs, learning tools and source of learning, the questions was answered by community members. While, the objective of second questionnaire was to measure the increasing of knowledge and understanding of community member who had attended training programs. The training materials consist of business management, financial management, product innovation, labelling and branding, business certifications and marketing strategy where delivered by academics and expertise. The training programs are classroombased and followed by one-on-one coaching in four months. 


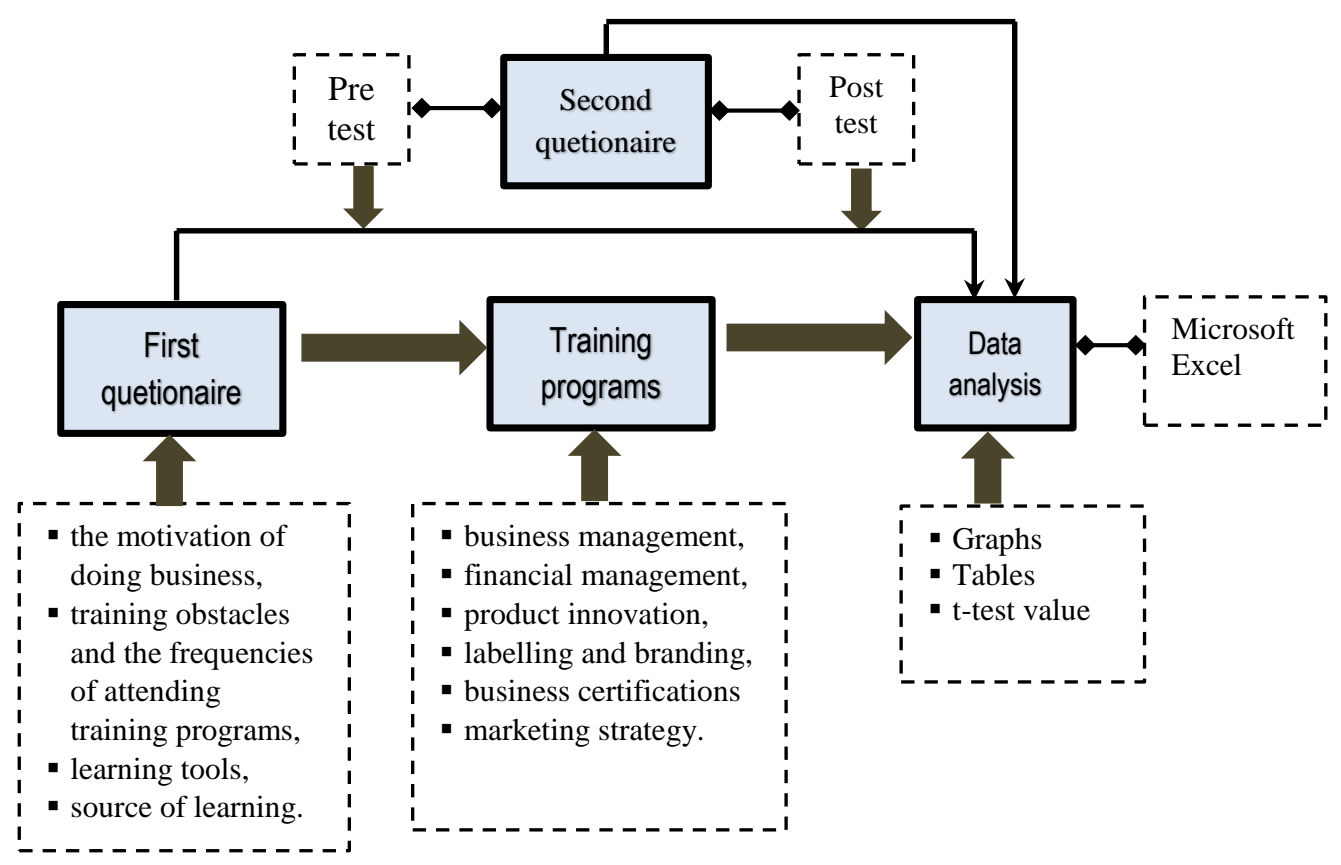

Figure 1. Schematic research methodology flow

Then, the data of first questionnaire were exported to and organized in Microsoft Excel which will produce graphs and tables. While the second questionnaire was analysed using paired $t$ test method to see the significance of change before and after training programs. Paired $t$ tests can be categorized as a type of $t$ test for a single sample due to the test done by the difference between two paired results (Kim, 2015).

\section{RESULTS AND DISCUSSIONS}

\section{Motivation}

Motivation is one of the keys for the entrepreneur to keep their persistent in doing business. The role of women in economic activities, especially through micro businesses, has proven to be helpful family economy and also help regional economic growth. Increasing number of entrepreneurs' women is inseparable from the internal and external driving factors. Factor identification is needed what drives a woman to start, organize and manage a business (Aimasari \& Gina, 2015). Female micro enterprises influenced by psychological, social, economic, physical and environment. Motivation is one of psychological impulse in directing someone to a business goal. Therefore, motivation is very important in business so that business goals are achieved and make business successful. The results show findings, that motivation and competence have an effect simultaneously on the success of female entrepreneurs (Prabandari \& Rosita, 2013). 


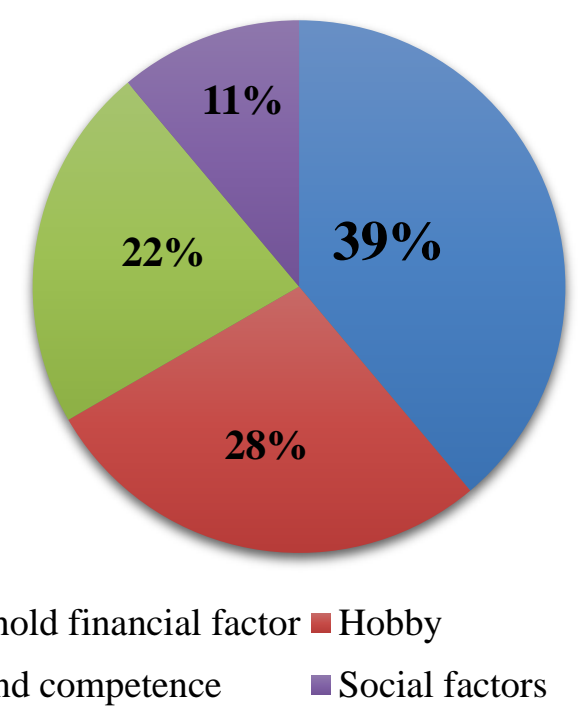

Figure 2. Motivation of female micro enterprises

Based on survey data that presented by Figure 2, research shows that the biggest motivation for female micro enterprises community members to do micro business activities is household financial factor. It is commonly occur in rural country such as Jakarta where the living cost becoming higher than others. Another reason is fact that most of community members are in middle-low economic status. This condition becomes worse because they don't have permanent jobs. Even though they live in the big city of Jakarta, the reality of getting a job is still very difficult. On the other hand they have responsibility to help the family economy. As an easiest way, they choose micro business activities for earning money. They can start from their kitchen and sell their product to community member. Hobby is the second reason why the community members doing micro business activities. Commonly, hobby is done for reasons of pleasure and not profit oriented. In contrast with business activities this is coming with economic idea cost-benefit principle. It is important to understand the difference between a hobby and a business. If the business is only done for reasons of pleasure, it will be difficult to achieve business goals properly. Moreover data shows that there are $22 \%$ community members who doing business due to skill and competence. Start micro business activities from skill and competence is good way but not enough. Skill and competence must be improved in line with business growth and market conditions. Training and coaching activities are the best way to improve and maximize the impact of skill and competence business success.

\section{Learning tools and sources}

The main problem faced by beginner entrepreneurs is the insight or knowledge of the business that is less mature. Even though this is a major investment and is very valuable for business continuity. This business knowledge includes how to start a business, make a simple plan, and design the right marketing, branding, packaging, product distribution, to the simple things and company administration. The source of business knowledge can be easily obtained such as by attending a business seminar or 
join the entrepreneurial community. Knowledge, skills and abilities are the core competencies of entrepreneurship to create special competitiveness in order to have a strong bargaining position in competition (Prabandari \& Rosita, 2013).

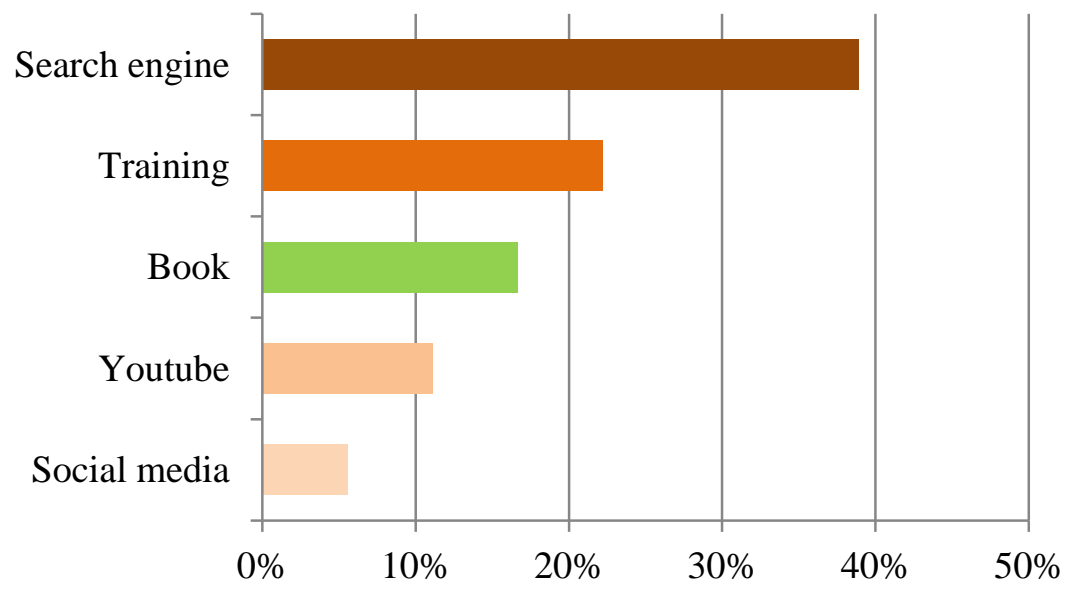

Figure 3. Learning tools of female micro enterprises

Figure 3 represent the learning tools commonly used by community members to seek business information. Almost $40 \%$ community members using search engine as learning media. Search engine is a service that allows internet users to search data for specified information for content via the World Wide Web (WWW) It is easily undestood that today information access via the internet is very easy. All of this business knowledge can be obtained easily without spend lot of money. Although the internet has provided various search engine such as Google, Bing, Yahoo, and ask that provide business information needed, but it still has limitation. The information contained from training programs and book is far more complete and in depth. As we know, business training is one of the most common forms of active support programs offered by university, non goverment organisation (NGO), goverment institutions or microfinance organisations.

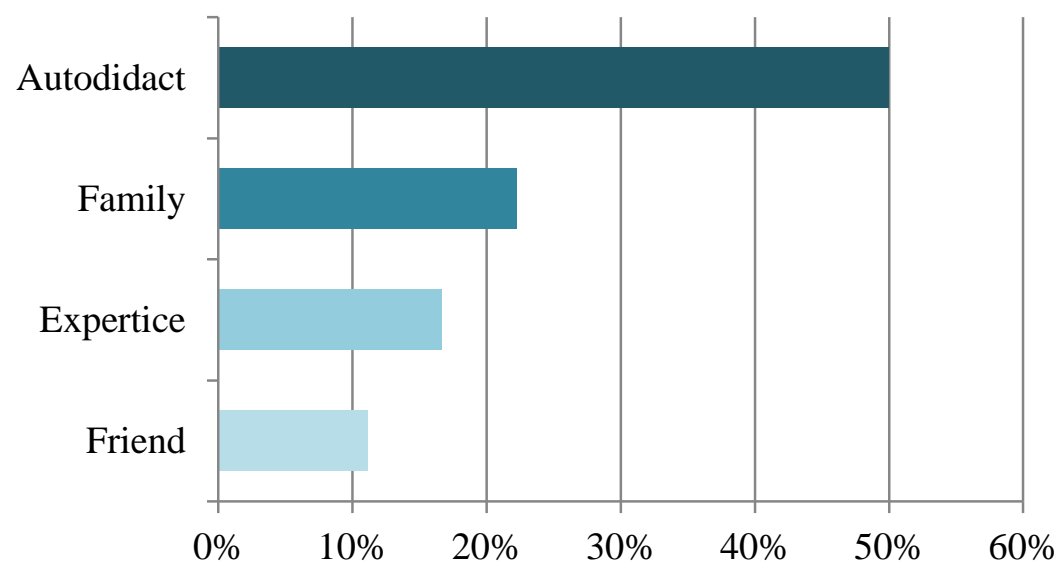

Figure 4. Learning sources of female micro enterprises 
Based on Figure 4, autodidact learning is the biggest method used by community members, this is not entirely wrong, but certainly will reduce the effectiveness and productivity of their business. The positive side of learning by autodidact are getting more specific knowledge as needed, easier and longer recorded by the human brain due to not only done by studying theory but also practicing. But the lack of this learning system is takes a longer time and no guidance.

Only less than $20 \%$ who learn from expertise. Even though learning from expertise is one of the fastest ways to accelerate the business growth. Finding mentor or coach who is far a head in business skills and competences is crucial to accelerate the business growth.

\section{Obstacles of Attending Training}

Female micro enterprises require a broad set of skills that includes risk management and opportunity recognition as well as business management skills. Public policy should help women overcome this skills barrier through training, coaching and mentoring programs. The objectives of entrepreneurship training programmes typically to increase the entrepreneur's know-how to start operate and manage business properly such as business and financial planning, identifying markets and customers behaviour, managing human resources etc. Eventhought there are a lot of training programs have offered from various institutions women still have limitation and obstacle to attend the training programs. It is due to lack of time, lack of information and lack of financing access.

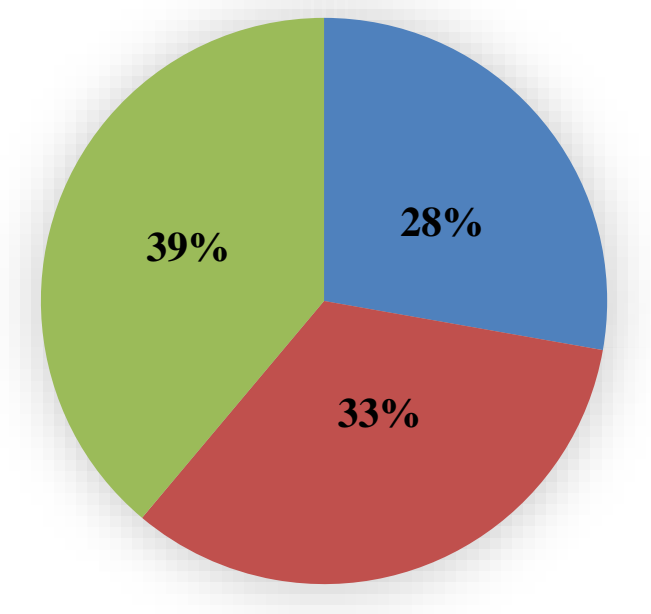

$\square$ Lack of financial investment $\square$ Lack of information $\square$ Lack of time

Figure 5. Obtacles of female micro enterprises attending training programs

In this study training has been given for free, and in addition some participants have also provided travel fee, snack and lunch. Despite training offered for free, the participation of community members did not $100 \%$. Only 18 from 30 community members who have commitment attend the training programs. Figure 5 shows the major obstacle facing with women entrepreneur to enhance their capability via participation on various training is lack of time that leads to lack of managerial issues. This is because women should able to make balance between their responsibility and work. Women 
have a very complex role. At the same time they was required to be a good child for his family, a good wife for her husband, a good mother for her child and must have a good role in her community. With such large responsibilities, women become quite difficult when they have to divide their time to work or take part in training.

\section{Knowledge Change after Training Program}

Training program for enterprises is one of the most complicated issues and a popular policy option to improve the enterprises around the world. Micro enterprises are facing a lot of problems such as poor of financial, lack of management and less skill. Entrepreneur training designed to develop skills knowledge and attitude for enterprises to start a new business or expand an existing one (Mayuran, 2016).

Table 1 shows the results of the pre-test and post-test scores after training. Data shows that the training gave a significant increase in knowledge to all participants in all aspects. This is evidenced by the value of $t$ test for all aspects of the assessment are 0 . Although the increasing value is significant for all aspect, the real impact of each aspect should be measure quantitatively and qualitatively. For example: in business management aspect might be expected to production performance and quality control practices, in financial management aspect give impact on cost efficiency, in product innovation and marketing strategy aspect results development of new product that increase sales and profit. To maximize the outcomes of training programs, it should be done in longer full-time which more content and discussions or designed as regular training program such as weekly training or monthly training. In addition, training materials should be delivered by experienced training professionals such as micro finance staff.

Tabel 1. The increasing knowledge of female micro enterprises through training program

\begin{tabular}{lcccc}
\hline \multirow{2}{*}{ Aspects } & \multicolumn{2}{c}{ Mean value } & The increasing & t-Test \\
value & value \\
\cline { 2 - 3 } & Pre test & Post test & & 0 \\
Business management & 34 & 70 & 36 & 0 \\
Financial management & 33 & 71 & 38 & 0 \\
Product innovation & 30 & 69 & 39 & 0 \\
Labelling and branding & 34 & 77 & 43 & 0 \\
Business certifications & 23 & 69 & 46 & 0 \\
Marketing strategy & 40 & 75 & 35 & \\
\hline
\end{tabular}

This study is found the training can increase the cognitive of the participant based on the table 1. However, this result does not guaranty the business will be running smoothly as we consider that business need other factors such as kinesthetic and intuitive of the participant 


\section{CONCLUSIONS}

Program penanganan dan pencegahan stunting yang telah dicanangkan pemerintah perlu dukungan berbagai pihak dalam hal implementasinya, baik akademisi maupun masyarakat. Upaya peningkatan kesadaran dan pengetahuan masyarakat mengenai stunting dan dampaknya serta upaya pencegahan dan penanganan stunting perlu terus dilakukan dalam pemberdayaan masyarakat untuk mempercepat mengatasi masalah stunting.

\section{Acknowledgements}

This research was collaboration and partnership between Universitas Bakrie and Female Micro Enterprises members in Pancoran-South of Jakarta. This research was funded by RISTEKDIKTI No 035/KM/PNT/2018 and Universitas Bakrie. The authors would like to thanks to all people who involved in this program.

\section{REFERENCES}

Aisyah, S., Musa, C. I., \& Ramli, A. (2017). Effect of characteristics and entrepreneurial orientation towards entrepreneurship competence and crafts and arts smes business performance in Makassar. International Review of Management and Marketing, 7(2), 166-173.

Aimasari, N., \& Ghina, S. (2015). Factor Analysis that motivate woman to become entrepreneur (A Study based on woman entrepreneur of micro, small and medium enterprises in the City of Bandung. E-Proceeding of Management 2(3), 2795-2799.

Al Mamun, A., Subramanian, P., Nawi N. B. C., \& Zainol, N. R. B. (2016). Entrepreneurial competencies and performance of informal micro enterprises in Malaysia. Mediterranean Journal of Social Science, 7(3), 273-281.

Behling, G. (2017). Entrepreneurial competencies and strategic behavior: a Study of micro entrepreneurs in an emerging country. Brazilian Business Review, 16(3), 256-272.

Eravia, D., Handayani, T., \& Julina. (2015). the Opportunities and threats of small and medium enterproses in Pekanbaru: Comparison between SMEs in food and restaurant industries. Procedia-Social and Behavioral Science, 169, 88-97.

Farvaque, N., Voss, E., Lefebvre, M., \& Schutze, K. (2009). Guide for training in SMEs. DGE employment, sosial affairs and equal opportunities. Brussel: Publications Office of the European Union.

Hani, U., Rachmania, I. N., Setyaningsih, S., \& Putri, R. C. (2012). Patterns of Indonesian women entrepreneurship. Procedia Economics and Finance, 4, 274-285. Irawati, R. (2018). Pengaruh pelatihan dan pembinaan terhadap pengembangan usaha kecil. Jurnal JIBEKA, 12(1), 74-82. 
Ismail, V. Y. (2014). The comparison of entrepreneurial competency in woman micro-, small, and medium-scale entrepreneurs. Procedia-Social and Behavioral Sciences, 115(1), 175-187.

Kim, T. K. (2015). T test as a parametric statistic. Korean Journal of Anesthesiology, 68(6), 540-546.

Mayuran, L. (2016). Impact of entrepreneurship training on performance of small enterprises in Jaffna district. Global Journal of Commerce and Management Perspective, 5(2), 1-6.

Ozsungur, F. (2019). A research on women's entrepreneurship motivation: Sample of Adana Province. Women's Studies International Forum, 74, 114-126.

Pandey, N. (2015). Women entrepreneurship: an effective and possible approach for women empowerment. International Journal of Development Research, 5(5), 4275-4279.

Prabandari, S, P., \& Rosita, N, H. (2013). Motivasi dan Kompetensi Pengaruhnya Terhadap Kesuksesan Pengusaha Wanita. Proceeding Seminar Nasional dan Call for Paper SANCALL 2013.

Schneider, K. (2017). Entrepreneurial competencies of women entrepreneurs of micro and small enterprises. Science Journal of Education, 5(6), 252-261.

Shmiln, A. W. (2017). Female entrepreneurs in developing countries: a comparative with developed countries as explorative study. Arabian Journal of Business and Management Review, 7(5), 1-5.

Siba, E. (2019). Empowering women entrepreneurs in developing countries: Why current programs fall short. Washington, DC: Africa Growth Initiative- Brookings Institution.

Tambunan, T. T. H. (2017). Women entrepreneurs in MSEs in Indonesia: their motivations and main constraints. International Journal of Gender and Women's Studies, $5(1), 56-86$.

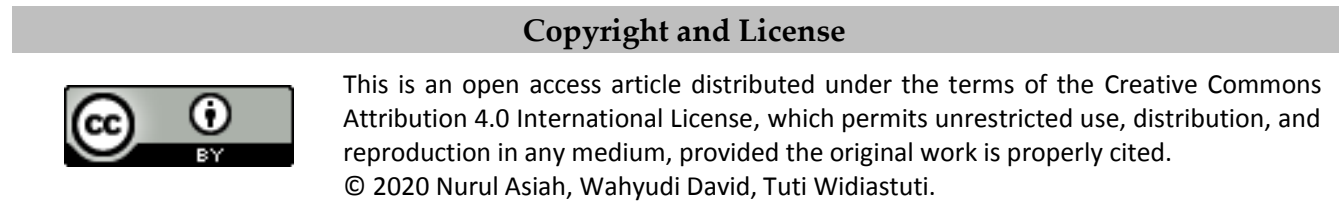

Published by LP3M of Universitas Mathla'ul Anwar Banten in collaboration with the Asosiasi Jurnal Pengabdian Kepada Masyarakat (AJPKM) 